\title{
Preparation of High Activity Ga and Cu Doped ZnS by Hydrothermal Method for Hydrogen Production under Visible Light Irradiation
}

\author{
Melody Kimi, ${ }^{1,2}$ Leny Yuliati, ${ }^{3}$ and Mustaffa Shamsuddin ${ }^{1}$ \\ ${ }^{1}$ Department of Chemistry, Faculty of Science, Universiti Teknologi Malaysia, 81310 Johor Bahru, Johor, Malaysia \\ ${ }^{2}$ Centre for Pre-University Studies, Universiti Malaysia Sarawak, 94300 Kota Samarahan, Sarawak, Malaysia \\ ${ }^{3}$ Ibnu Sina Institute for Fundamental Science Studies, Universiti Teknologi Malaysia, 81310 Johor Bahru, Johor, Malaysia \\ Correspondence should be addressed to Melody Kimi; kmelody@preuni.unimas.my
}

Received 6 May 2015; Accepted 14 July 2015

Academic Editor: Balachandran Jeyadevan

Copyright (C) 2015 Melody Kimi et al. This is an open access article distributed under the Creative Commons Attribution License, which permits unrestricted use, distribution, and reproduction in any medium, provided the original work is properly cited.

$\mathrm{Ga}(0.1), \mathrm{Cu}(x)-\mathrm{ZnS}(x=0.01,0.03,0.05)$ photocatalysts were successfully synthesized by hydrothermal method. The synthesized $\mathrm{Ga}$ and $\mathrm{Cu}$ codoped $\mathrm{ZnS}$ photocatalysts showed photocatalytic property effective for hydrogen production from aqueous solution containing $\mathrm{Na}_{2} \mathrm{SO}_{3}$ and $\mathrm{Na}_{2} \mathrm{~S}$ as sacrificial reagent under visible light irradiation. The rate of hydrogen production was found to be strongly dependent on $\mathrm{Cu}$ doping content. The highest photocatalytic activity is observed for $\mathrm{Ga}(0.1), \mathrm{Cu}(0.01)-\mathrm{ZnS}$ with hydrogen production rate of $114 \mu \mathrm{mol} / \mathrm{h}$. The addition of $\mathrm{Ga}$ as codoped increased the photocatalytic activity to 58 times as compared to single doped $\mathrm{Cu}-\mathrm{ZnS}$. The $\mathrm{Ga}$ and $\mathrm{Cu}$ codoped $\mathrm{ZnS}$ photocatalysts are also stable under long irradiation. The enhancement in the photocatalytic activity of $\mathrm{Ga}$ and $\mathrm{Cu}$ codoped photocatalyst can be attributed to the synergistic effect between $\mathrm{Ga}$ and $\mathrm{Cu}$. The photocatalytic activity was greatly enhanced with the addition of $0.5 \mathrm{wt} \% \mathrm{Ru}$ as cocatalyst with a hydrogen production rate of $744 \mu \mathrm{mol} / \mathrm{h}$.

\section{Introduction}

Hydrogen, an attractive clean energy source with high energy capacity, is a very promising candidate as a primary energy source in the future $[1,2]$. Photocatalytic water splitting is considered as an alternative method to produce hydrogen utilizing solar energy. Up to now, considerable efforts have been devoted to developing highly active photocatalysts for the water splitting reaction and remarkable progress has been made [3-6].

$\mathrm{ZnS}$ is known to be a highly active photocatalyst for hydrogen evolution from aqueous solutions containing sacrificial reagents such as $\mathrm{SO}_{3}{ }^{2-}$ and $\mathrm{S}^{2-}$, even without the addition of Pt cocatalyst. This is due to the high conduction band level of $\mathrm{ZnS}$ to reduce water to hydrogen [7-9]. However, the large band gap of $\mathrm{ZnS}$ restricts its photocatalytic applications within the UV light range. To effectively utilize solar light energy, visible light response photocatalysts with high photocatalytic activity are desired.
Doping of $\mathrm{ZnS}$ is considered as one of the many ways to enhance the light absorption ability of $\mathrm{ZnS}$ to the visible light region while still maintaining the high conduction band. $\mathrm{Cu}$ doped $\mathrm{ZnS}$ [10, 11], Ni doped ZnS [12], and Bi doped $\mathrm{ZnS}$ [13] have been reported to show considerable high photocatalytic activities for hydrogen evolution under visible light from aqueous solution containing $\mathrm{S}^{2-}$ and/or $\mathrm{SO}_{3}{ }^{2-}$ as electron donors. The visible light response is obtained by the formation of donor levels by the doped metal cations in the wide band gap of the $\mathrm{ZnS}$ host material.

Although $\mathrm{Cu}$ doped $\mathrm{ZnS}$ [10] showed high photocatalytic activity for hydrogen evolution, it suffers from photocorrosion. One of the possible methods to maintain the high photocatalytic activity of $\mathrm{Cu}$ doped $\mathrm{ZnS}$ without suffering from photocorrosion is to carry out doping with another metal. It is known that codoping is effective to suppress the recombination rate of electron-hole pairs $[14,15]$. This is due to the synergic effects produced when two metals are doped together. The negative effects caused by doping 
can be partially improved by codoping with another dopant. Dopants like $\mathrm{Sn}^{4+}$ and $\mathrm{Eu}^{3+}$ were incorporated in $\mathrm{TiO}_{2}$ to improve the visible light absorption and photocatalytic activity. The purpose of using Sn and Eu was that the former is known to help in the charge separation of photogenerated electrons and holes and the latter being a lower valent cation than $\mathrm{Ti}^{4+}$ can generate anion vacancies in $\mathrm{TiO}_{2}$ thereby leading to visible light absorption [14].

Ga doped ZnS has been reported to be photocatalytically active under UV light irradiation [16]. In addition to the absorption spectrum, the mobility of photogenerated charges is critical for photocatalytic activity. Metal compounds associated with $\mathrm{d}^{10}$ electronic configurations such as $\mathrm{Ga}^{3+}$ are attractive because their conduction and valence bands are formed by hybridized sp orbitals with large band dispersion that would lead to high charge mobility and, hence, high photocatalytic performance $[17,18]$. Ga was selected as the dopant in this study as it is regarded as the most efficient donor for $\mathrm{ZnS}$ to generate more charge carriers [19].

This present study aims to investigate the exact role of synergistic effect of codoping $\mathrm{Ga}$ and $\mathrm{Cu}$ into $\mathrm{ZnS}$ lattice in the physical-chemical properties and photocatalytic activity for hydrogen production. The new photocatalyst $\mathrm{Ga}, \mathrm{Cu}$ codoped $\mathrm{ZnS}$ was prepared by using hydrothermal method. The role of $\mathrm{Ga}$ in promoting the photocatalytic activity was also examined.

\section{Experimental}

2.1. Synthesis of Samples. Simple hydrothermal method was used to synthesize the powder samples of $\mathrm{ZnS}, \mathrm{Cu}(0.1)-\mathrm{ZnS}$, $\mathrm{Ga}(0.1)-\mathrm{ZnS}$, and $\mathrm{Ga}(0.1), \mathrm{Cu}(x)-\mathrm{ZnS}(x=0.01,0.03,0.05)$ in a similar way to the previous literatures $[20,21]$. The samples were labelled as $\mathrm{Ga}(0.1), \mathrm{Cu}(x)-\mathrm{ZnS}$, with $x$ showing the doping amount of $\mathrm{Cu}$ in mol ratio. In a typical synthesis for $\mathrm{Ga}(0.1), \mathrm{Cu}(0.01)-\mathrm{ZnS}, 0.2 \mathrm{mmol}$ of $\mathrm{Cu}\left(\mathrm{NO}_{3}\right)_{2} \cdot 3 \mathrm{H}_{2} \mathrm{O}$ (Fluka, 98\%), $2 \mathrm{mmol}$ of $\mathrm{Ga}\left(\mathrm{NO}_{3}\right)_{2} \cdot x \mathrm{H}_{2} \mathrm{O}$ (Aldrich, 99.9\%), $18 \mathrm{mmol}$ of $\mathrm{Zn}\left(\mathrm{CH}_{3} \mathrm{COO}\right)_{2} \cdot 2 \mathrm{H}_{2} \mathrm{O}$ (GCE chemicals, 98\%), and $20 \mathrm{mmol}$ of $\mathrm{CH}_{3} \mathrm{CSNH}_{2}$ (Merck, 99\%) were dissolved in $50 \mathrm{~mL}$ of distilled water. The solution was added to an autoclave that was sealed and heated in an oven at $433 \mathrm{~K}$ for $8 \mathrm{~h}$. After natural cooling to room temperature, the precipitates were washed with distilled water for several times and dried in vacuum at room temperature.

2.2. Characterization. Powder X-ray diffraction (XRD) patterns were obtained with an X-ray diffractometer, Bruker Advance D8 Siemens 5000 using $\mathrm{Cu} \mathrm{K} \alpha$ radiation $(\lambda=$ $0.15418 \mathrm{~nm}, 40 \mathrm{kV}, 40 \mathrm{~mA}$ ). The diffuse reflectance UVvisible (DR UV-vis) spectra were recorded on a Perkin Elmer Ultraviolet-Visible Spectrometer Lambda 900. Barium sulfate $\left(\mathrm{BaSO}_{4}\right)$ was used as the reference. Photoluminescence $(\mathrm{PL})$ spectra were measured at room temperature using a photoluminescence spectrophotometer (PTI QM4) with an excitation wavelength of $250 \mathrm{~nm}$. The morphologies and crystal sizes of the samples were determined with field emission scanning electron microscopy (FESEM) using JEOL JSM 6701F with platinum coating $(2 \mathrm{kV}, 10 \mathrm{~mA})$. Specific surface area was measured using the
Brunauer-Emmett-Teller (BET) method, Beckman Coulter SA3100 by nitrogen absorption at $77 \mathrm{~K}$. The samples were previously outgassed at $393 \mathrm{~K}$ for $180 \mathrm{~min}$. The elemental analysis was completed on a Bruker S4 PIONEER X-ray fluorescence $(\mathrm{XRF})$ spectrum, using $\mathrm{Ru}$ target and $4 \mathrm{~kW}$ power.

The chemical forms of the products were studied using X-ray photoelectron spectroscopy (XPS), AXIS Ultra DLD, Shimadzu, with monochromatic $\mathrm{Al} \mathrm{K} \alpha$ radiation $(1486.6 \mathrm{eV})$.

2.3. Photocatalytic Activities. Photocatalytic hydrogen evolution was performed in a closed-side irradiated-Pyrex cell equipped with an outer water cooling system to keep the temperature throughout the reaction at $25 \pm 0.2^{\circ} \mathrm{C}$. In all experiments, the powder sample $(0.2 \mathrm{~g})$ was dispersed by magnetic stirring in an aqueous solution $(190 \mathrm{~mL})$ containing $0.25 \mathrm{M} \mathrm{Na}_{2} \mathrm{SO}_{3}$ and $0.35 \mathrm{M} \mathrm{Na}_{2} \mathrm{~S}$ [20] as sacrificial agents. Nitrogen gas was purged through the reaction cell for $30 \mathrm{~min}$ before reaction to remove air. A $300 \mathrm{~W}$ Xe lamp was focused on the side window of the cell through a cut-off filter $(\lambda \geq$ $425 \mathrm{~nm}$, TrusTech PLS-SXE 300). The apparent quantum yields (AQY) defined by (1) were measured using a $425 \mathrm{~nm}$ band pass filter and Avantes fibre optic spectrometer (Ava Spec USB 2000) connected to AveSoft 7.2. The amount of hydrogen evolved was determined with a thermal conductivity detector (TCD) gas chromatography (SP 2100) using $\mathrm{NaX}$ zeolite column and nitrogen as carrier gas. Cocatalyst ruthenium (0.1-1 wt\%) was loaded on the photocatalyst surface by an in situ photodeposition method from the precursor of $\mathrm{RuCl}_{3}$. Consider

$$
\begin{aligned}
\operatorname{AQY}(\%) & =\frac{\text { number of reacted electrons }}{\text { number of incident photons }} \times 100 \\
& =\frac{\text { number of evolved } \mathrm{H}_{2} \text { molecules }}{\text { number of incident photons }} \times 2 .
\end{aligned}
$$

\section{Results and Discussion}

3.1. Crystal Structure. Figure 1 shows XRD patterns of ZnS, $\mathrm{Cu}(0.1)-\mathrm{ZnS}, \mathrm{Ga}(0.1)-\mathrm{ZnS}$, and $\mathrm{Ga}(0.1), \mathrm{Cu}(x)-\mathrm{ZnS}$ powder samples. The distinctive peaks are found at $2 \theta$ of $28.6,32.5$, 47.6 , and 56.3, corresponding to the (111), (200), (220), and (311) planes, respectively, which is a typical pattern of cubic zinc blende phase [22, 23]. For $\mathrm{ZnS}$, there is shoulder peak at $2 \theta=27$. This is due to (100) and (002) plane hexagonal phase of $\mathrm{ZnS}$, which is in agreement with the reported values with similar synthesis temperature [24]. As for the $\mathrm{Cu}(0.1)$ $\mathrm{ZnS}$ sample, there is a broad shoulder peak at $2 \theta=27$ which might be due to the (101) plane of CuS [25]. This peak has a different shape compared to the shoulder peak of $\mathrm{ZnS}$ at the same place. Furthermore, the peak at $2 \theta=30.5$ also disappeared for $\mathrm{Cu}(0.1)-\mathrm{ZnS}$. It is also observed that there is a shoulder peak at $2 \theta=33.5$ and $2 \theta=59$ corresponding to (006) and (116) plane of CuS, respectively [26, 27]. This confirms that, for $\mathrm{Cu}(0.1)-\mathrm{ZnS}$, both $\mathrm{CuS}$ and $\mathrm{ZnS}$ phases existed in the sample.

The peak became broad with the addition of Ga to the samples; thus the weak diffraction peak at (200) was not 


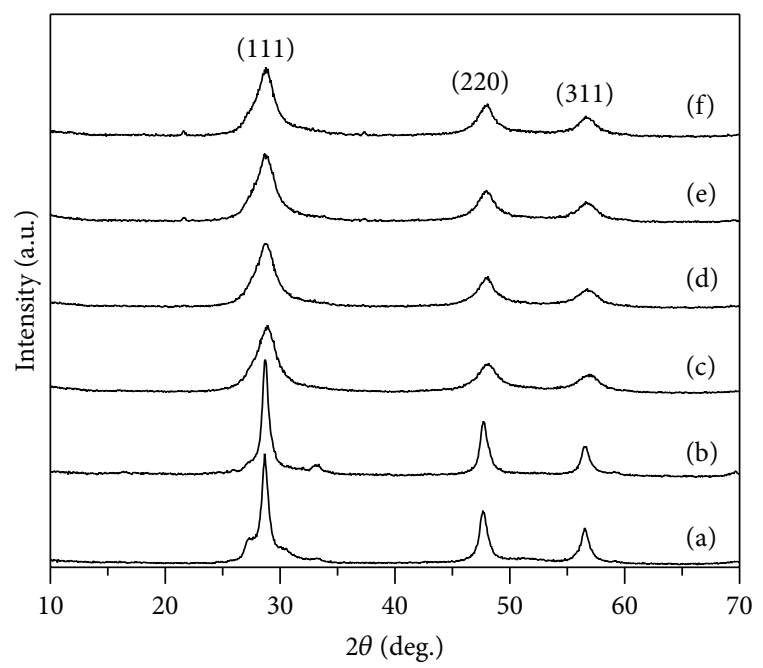

FIGURE 1: XRD patterns of (a) ZnS, (b) $\mathrm{Cu}(0.1)-\mathrm{ZnS}$, (c) $\mathrm{Ga}(0.1)$ $\mathrm{ZnS}$, (d) $\mathrm{Ga}(0.1), \mathrm{Cu}(0.01)-\mathrm{ZnS}$, (e) $\mathrm{Ga}(0.1), \mathrm{Cu}(0.03)-\mathrm{ZnS}$, and (f) $\mathrm{Ga}(0.1), \mathrm{Cu}(0.05)-\mathrm{ZnS}$.

observed. $\mathrm{Ga}(0.1), \mathrm{Cu}(x)$-ZnS samples showed well developed cubic zinc blende phase without any impurity phase or elements. No peaks corresponding to metallic $\mathrm{Ga}$ or $\mathrm{Cu}$ or oxides were observed in the XRD pattern because of the low dopant concentration. This could also be due to the highly dispersed $\mathrm{Ga}$ and $\mathrm{Cu}$ in or on the $\mathrm{ZnS}$ particle.

The diffraction peaks of $\mathrm{ZnS}$ were intense, suggesting a well crystallized sample. For $\mathrm{Cu}(0.1)-\mathrm{ZnS}$, the peak intensity increased and became sharper, indicating an increase in crystallinity. This suggests that $\mathrm{Cu}$ promotes the crystal growth due to crystal metallization effect [28]. In contrast, for $\mathrm{Ga}(0.1)-\mathrm{ZnS}$ and $\mathrm{Ga}(0.1), \mathrm{Cu}(\mathrm{x})-\mathrm{ZnS}$ samples, they showed broad and weak diffraction peaks. This is probably due to the the low crystallinity caused by defect sites or the addition of $\mathrm{Ga}$ inhibited crystal growth. However, as the amount of $\mathrm{Cu}$ dopant increased from 0.01 to $0.05 \mathrm{~mol}$, there were no changes in peak intensities. This indicates that the amount of $\mathrm{Cu}$ did not have any effect on the crystal structure.

There was no peak shifting from $\mathrm{ZnS}$ when only $\mathrm{Cu}$ was doped into $\mathrm{ZnS}$ due to similar ionic radii of $\mathrm{Cu}^{2+}(0.72 \AA)$ and $\mathrm{Zn}^{2+}(0.74 \AA)$. However, for $\mathrm{Ga}(0.1)-\mathrm{ZnS}$ and $\mathrm{Ga}(0.1), \mathrm{Cu}(x)$ $\mathrm{ZnS}$ samples, there was slight shifting of peak to higher angle. This might be due to the smaller ionic radius of $\mathrm{Ga}^{3+}(0.62 \AA)$ compared to $\mathrm{Zn}^{2+}$ which means $\mathrm{Ga}$ ions easily enter the lattice of $\mathrm{ZnS}$ without causing distortion.

The crystallite size of the prepared samples is calculated from the (111) diffraction peak using Scherrer equation as shown in Table 1. From Table 1, it was revealed that, in the presence of $\mathrm{Cu}$ in $\mathrm{ZnS}$, the crystallite size increased which is confirmed from the increase in peak intensity. The decrease in crystallite size can be observed for all Ga doped $\mathrm{ZnS}$ samples, which suggests that Ga inhibits the growth of crystal. The slight increase of crystallite size when the amount of $\mathrm{Cu}$ was increased in the $\mathrm{Ga}(0.1), \mathrm{Cu}(x)-\mathrm{ZnS}$ samples could be attributed to the larger ionic radius of $\mathrm{Cu}$ from $\mathrm{Ga}$. From Table 1, the slight changes in d-spacing and lattice parameter for all the $\mathrm{Ga}(0.1), \mathrm{Cu}(x)-\mathrm{ZnS}$ from $\mathrm{ZnS}$ indicated that some substitution of $\mathrm{Zn}^{2+}$ ions by the doping metal ions had taken place. For $\mathrm{Cu}(0.1)-\mathrm{ZnS}$, the lattice parameter decreased compared to $\mathrm{ZnS}$; this may be caused by the substitution of $\mathrm{Zn}^{2+}(0.74 \AA)$ by $\mathrm{Cu}^{2+}(0.72 \AA)$. The same pattern was observed with $\mathrm{Ga}(0.1)-\mathrm{ZnS}$. For $\mathrm{Ga}(0.1), \mathrm{Cu}(x)$ $\mathrm{ZnS}$, the lattice parameter remained unchanged regardless of the $\mathrm{Cu}$ amount, indicating that no further substitution has taken place above $\mathrm{Cu}$ content of 0.01 .

3.2. Morphology. The FESEM images of $\mathrm{ZnS}, \mathrm{Cu}(0.1)-\mathrm{ZnS}$, $\mathrm{Ga}(0.1)-\mathrm{ZnS}$, and $\mathrm{Ga}(0.1), \mathrm{Cu}(x)-\mathrm{ZnS}$ are shown in Figure 2. The particles size of $\mathrm{ZnS}$ and $\mathrm{Cu}(0.1)-\mathrm{ZnS}$ ranges from 20 to $150 \mathrm{~nm}$. The nanospheres agglomerated into a bigger undefined shape. As Ga was doped into $\mathrm{ZnS}$, the smaller nanospheres in the range of $10 \mathrm{~nm}$ to $50 \mathrm{~nm}$ compacted and agglomerated into bigger spheres in the range of $1 \mu \mathrm{m}$. The substitution of $\mathrm{Zn}$ by Ga ions might cause the formation of defects due to different ionic radius. The increase in defect sites inhibits the growth of crystal. The smaller nanospheres observed which are formed by the addition of Ga were confirmed by the weak and broad intensities of XRD peaks. The smaller size of nanospheres with the addition of Ga can be ascribed to the Ga localizing near the surface of crystal which prevented crystal growth. $\mathrm{Ga}(0.1), \mathrm{Cu}(x)$ - $\mathrm{ZnS}$ have smaller single sphere that makes it easier to agglomerate into bigger spheres compared to $\mathrm{ZnS}$. It can be deduced that the addition of $\mathrm{Ga}$ led to the formation of sphere shaped particles.

From the BET analysis in Table 1, ZnS had a surface area of $57 \mathrm{~m}^{2} / \mathrm{g}$. For $\mathrm{Cu}(0.1)-\mathrm{ZnS}$, as the particle size becomes larger due to the presence of $\mathrm{Cu}$, the surface area decreases to $38 \mathrm{~m}^{2} / \mathrm{g}$. The addition of Ga dopant increased the specific surface area for $\mathrm{Ga}(0.1)-\mathrm{ZnS}$ and $\mathrm{Ga}(0.1), \mathrm{Cu}(0.01)-\mathrm{ZnS}$. This is in good agreement with the XRD and FESEM results. On the other hand, decrease in specific surface area is observed when the samples had higher amount of $\mathrm{Cu}$ dopant. It can be suggested that the excess $\mathrm{Cu}$ on the catalyst surface led to the decrease in surface area.

\subsection{Optical Properties}

3.3.1. Diffuse Reflectance UV-Visible Spectra. The absorption spectra of investigated samples are shown in Figure 3. The onset of the absorption edge of $\mathrm{ZnS}$ is at $400 \mathrm{~nm}$ in the UV absorption region, corresponding to the band gap of $3.25 \mathrm{eV}$, which is slightly lower than the value usually reported (3.6$3.7 \mathrm{eV})[29,30]$. This might be due to the synthesis procedure which resulted in defects that might decrease the band gap energy [11]. It can be seen from Figure 3(b) that extended absorption is generated in the visible light region when $\mathrm{Cu}$ is doped. A large absorption shoulder at $550 \mathrm{~nm}$ to $800 \mathrm{~nm}$ was observed for $\mathrm{Cu}(0.1)-\mathrm{ZnS}$ which may be due to $\mathrm{Cu}$ d$\mathrm{d}$ transition in a large amount. The shoulder peak around $400 \mathrm{~nm}$ [31] and around $650 \mathrm{~nm}$ [25] shows the existence of $\mathrm{CuS}$ phase in the $\mathrm{Cu}(0.1)-\mathrm{ZnS}$ as confirmed by XRD. As for $\mathrm{Ga}(0.1)-\mathrm{ZnS}$, only a slight shift to longer wavelength from $\mathrm{ZnS}$ but not to the visible light region was observed. This could be deduced from the formation of defects from the doping of $\mathrm{Ga}$ into the $\mathrm{Zn}$ lattices. 


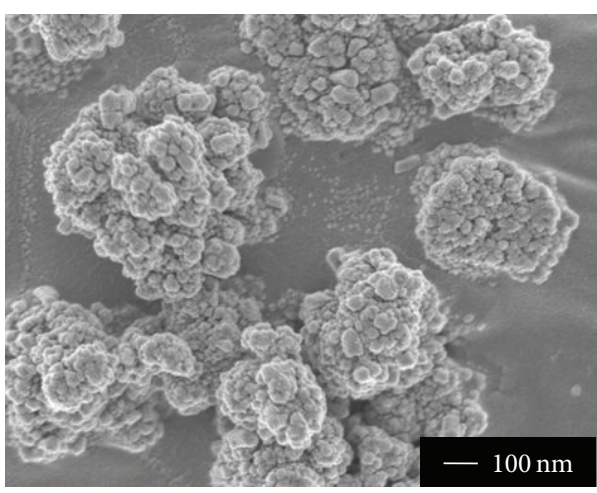

(a)

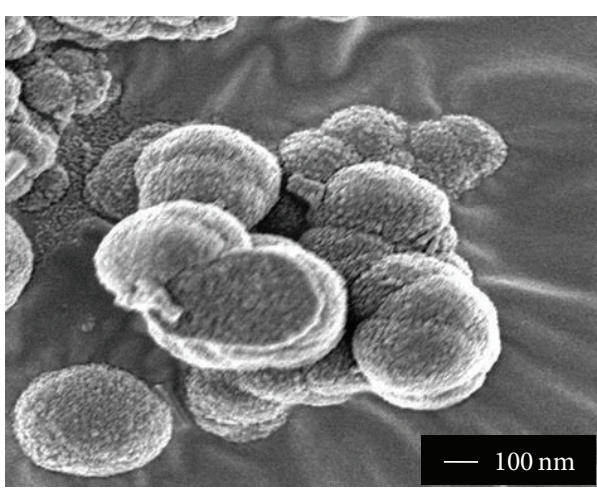

(c)

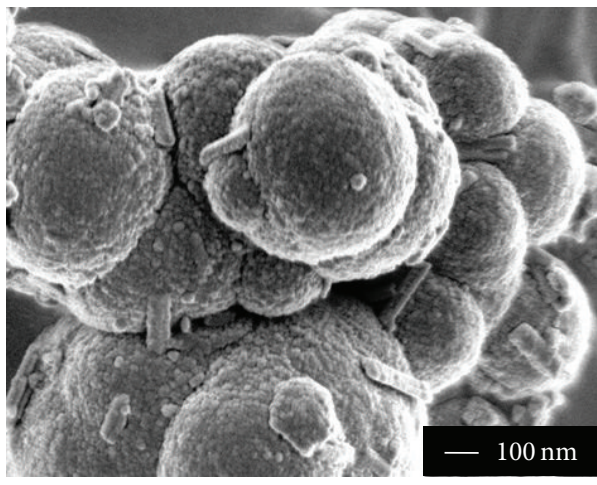

(e)

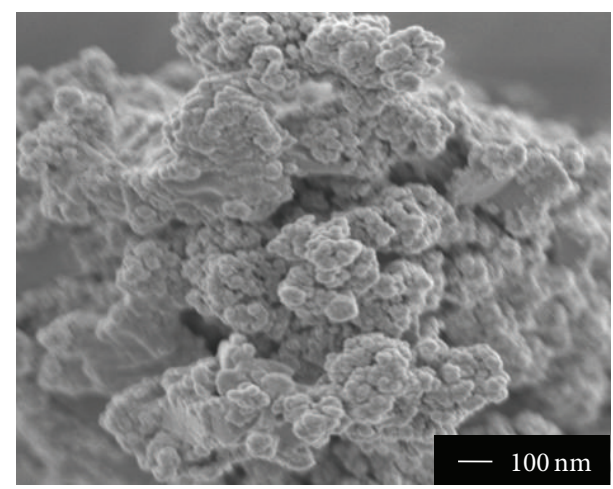

(b)

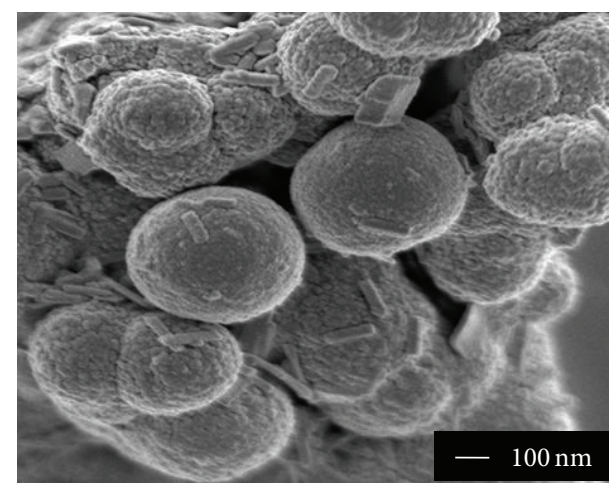

(d)

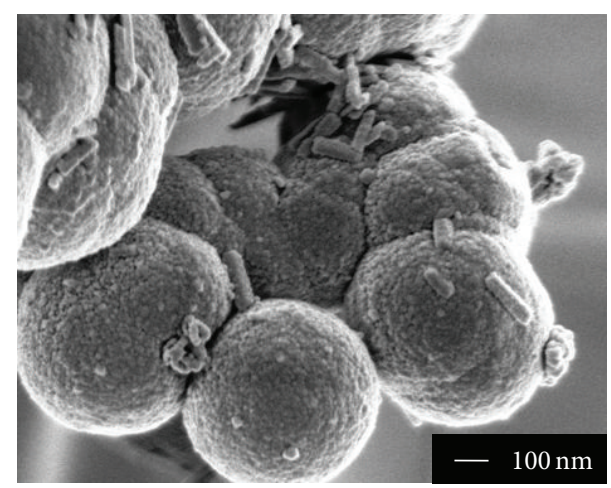

(f)

Figure 2: FESEM images of (a) ZnS, (b) $\mathrm{Cu}(0.1)-\mathrm{ZnS}$, (c) Ga(0.1)-ZnS, (d) $\mathrm{Ga}(0.1), \mathrm{Cu}(0.01)-\mathrm{ZnS}$, (e) $\mathrm{Ga}(0.1), \mathrm{Cu}(0.03)-\mathrm{ZnS}$, and (f) $\mathrm{Ga}(0.1), \mathrm{Cu}(0.05)-\mathrm{ZnS}$.

As for $\mathrm{Ga}(0.1), \mathrm{Cu}(x)-\mathrm{ZnS}$ samples, with increasing amount of $\mathrm{Cu}$ dopant, the absorption edges gradually shifted to longer wavelength. The absorption edge of $\mathrm{Ga}(0.1), \mathrm{Cu}(x)$ $\mathrm{ZnS}$ is located between that of $\mathrm{ZnS}$ and that of $\mathrm{Cu}(0.1)-\mathrm{ZnS}$ and shifts monotonously from $490 \mathrm{~nm}$ to $550 \mathrm{~nm}$ with an increase in $x$ from 0.01 to 0.05 . As the amount of $\mathrm{Cu}$ increased, the intensity of the absorption tail at $550 \mathrm{~nm}$ to $800 \mathrm{~nm}$ also increased due to the $\mathrm{Cu} \mathrm{d}$-d transition of $\mathrm{Cu}^{2+}$ $[10,11,32,33]$. This suggests that more $\mathrm{Cu}$ is present on the surface of the samples. The extension of the absorption edge to the visible region and increasing absorption tail implied that $\mathrm{Cu}$ was incorporated not only into the lattice of $\mathrm{ZnS}$ but also on the surface.
Comparing the spectra of $\mathrm{Ga}(0.1)-\mathrm{ZnS}$ and $\mathrm{Cu}(0.1)$ $\mathrm{ZnS}$, it can be concluded that the visible light response of $\mathrm{Ga}(0.1), \mathrm{Cu}(x)-\mathrm{ZnS}$ is derived from the doping of $\mathrm{Cu}$ instead of $\mathrm{Ga}$. It can be deduced that the absorption edge around $500 \mathrm{~nm}$ was due to the charge transfer from $\mathrm{Cu}^{2+} 3 \mathrm{~d}$ orbital to $\mathrm{Zn} 4 \mathrm{~s} 4 \mathrm{p}$ orbital. The absorption tail observed above $550 \mathrm{~nm}$ could be ascribed to d-d transition of $\mathrm{Cu}$ in the $\mathrm{Ga}(0.1), \mathrm{Cu}(x)$ $\mathrm{ZnS}$ samples. The doped $\mathrm{Cu}$ forms a new energy level in the band structure of $\mathrm{Ga}(0.1)-\mathrm{ZnS}$. The charge transfer from donor levels formed by $\mathrm{Cu} 3 \mathrm{~d}$ to the conduction band leads to the visible light response.

The band gap energies of the samples were estimated from Tauc's plots as seen in Table 1. The valence band of 
TABLE 1: Properties of $\mathrm{ZnS}$ and $\mathrm{ZnS}$ doped samples.

\begin{tabular}{|c|c|c|c|c|c|c|}
\hline Entry & Samples & $\begin{array}{c}d_{111} \text { value }^{\mathrm{a}} \\
(\AA)\end{array}$ & $\begin{array}{c}\text { Lattice } \\
\text { parameter, } a^{\mathrm{b}} \\
(\mathrm{nm})\end{array}$ & $\begin{array}{l}\text { Crystallite size } \\
\quad d^{c}(\mathrm{~nm})\end{array}$ & $\begin{array}{l}\text { Band gap } \\
(\mathrm{eV})^{\mathrm{d}}\end{array}$ & $\begin{array}{c}\text { Surface area } \\
\left(\mathrm{m}^{2} / \mathrm{g}\right)\end{array}$ \\
\hline 1 & $\mathrm{ZnS}$ & 3.1121 & 5.3903 & 11.76 & 3.25 & 57 \\
\hline 2 & $\mathrm{Cu}(0.1)-\mathrm{ZnS}$ & 3.1068 & 5.3811 & 12.51 & 1.75 & 39 \\
\hline 3 & $\mathrm{Ga}(0.1)-\mathrm{ZnS}$ & 3.0857 & 5.3447 & 4.48 & 3.02 & 113 \\
\hline 4 & $\mathrm{Ga}(0.1), \mathrm{Cu}(0.01)-\mathrm{ZnS}$ & 3.1015 & 5.3719 & 4.47 & 2.48 & 84 \\
\hline 5 & $\mathrm{Ga}(0.1), \mathrm{Cu}(0.03)-\mathrm{ZnS}$ & 3.1015 & 5.3719 & 4.65 & 2.32 & 14 \\
\hline 6 & $\mathrm{Ga}(0.1), \mathrm{Cu}(0.05)-\mathrm{ZnS}$ & 3.1015 & 5.3719 & 4.80 & 2.20 & 12 \\
\hline
\end{tabular}

${ }^{a}$ The value was calculated from $2 d_{111} \sin \theta=n \lambda$.

${ }^{\mathrm{b}}$ The value was calculated from $a=d_{111} \sqrt{3}$.

${ }^{c}$ The value was calculated from Scherrer equation.

${ }^{\mathrm{d}}$ The value was obtained from Tauc Plot.

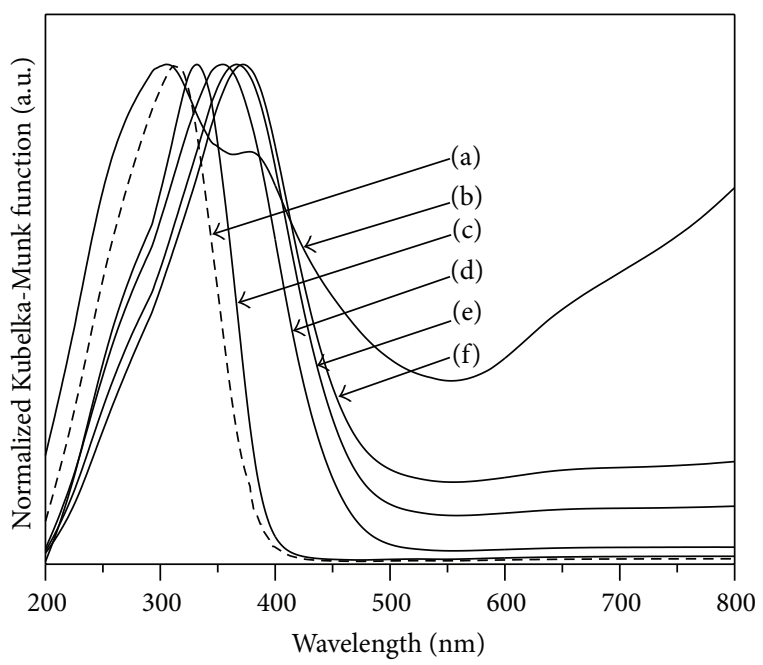

FIGURE 3: DR UV-visible spectra of (a) ZnS, (b) $\mathrm{Cu}(0.1)-\mathrm{ZnS}$, (c) $\mathrm{Ga}(0.1)-\mathrm{ZnS}$, (d) $\mathrm{Ga}(0.1), \mathrm{Cu}(0.01)-\mathrm{ZnS}$, (e) $\mathrm{Ga}(0.1), \mathrm{Cu}(0.03)-\mathrm{ZnS}$, and (f) $\mathrm{Ga}(0.1), \mathrm{Cu}(0.05)-\mathrm{ZnS}$.

$\mathrm{Ga}(0.1), \mathrm{Cu}(x)-\mathrm{ZnS}$ consists of donor levels of $\mathrm{Cu} 3 \mathrm{~d}$ formed above the $\mathrm{S} 3 \mathrm{p}$ valence band. The band gap of $\mathrm{Ga}(0.1), \mathrm{Cu}(x)-$ $\mathrm{ZnS}$ samples decreased with increasing $\mathrm{Cu}$ amount. Visible light absorption was only observed for samples doped with $\mathrm{Cu}$. Therefore, the $\mathrm{Cu}$ metal ions play an important role in the absorption bands observed in the visible light region.

3.3.2. Photoluminescence Spectra. Figure 4 shows the comparison of photoluminescence $(\mathrm{PL})$ spectra for all the samples in the range of $340 \mathrm{~nm}$ to $800 \mathrm{~nm}$ from the excitation wavelength of $250 \mathrm{~nm}$. The intensity of the peak for $\mathrm{ZnS}$ and $\mathrm{Ga}(0.1)-\mathrm{ZnS}$ is much stronger compared to the other samples, suggesting that these samples have high crystal quality with few defects. ZnS sample showed an absorption peak centered at $400 \mathrm{~nm}$ which might arise from electronhole recombination. Three other broad peaks centered at $470 \mathrm{~nm}, 560 \mathrm{~nm}$, and $690 \mathrm{~nm}$ were also observed. The broad peaks might be due to trap state emission arising from defect sites. The addition of dopant metal ions modifies the surface defect sites which in turn enhances or quenches the PL band.

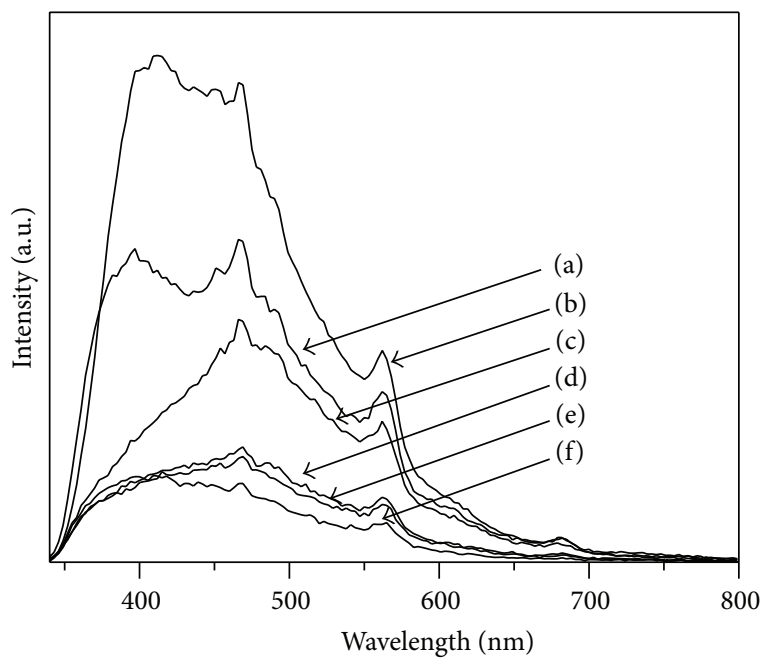

Figure 4: PL spectra of (a) ZnS, (b) Ga(0.1)-ZnS, (c) Ga(0.1), $\mathrm{Cu}(0.01)-\mathrm{ZnS}$, (d) $\mathrm{Ga}(0.1), \mathrm{Cu}(0.03)-\mathrm{ZnS}$, (e) $\mathrm{Ga}(0.1), \mathrm{Cu}(0.05)-\mathrm{ZnS}$, and (f) $\mathrm{Cu}(0.1)-\mathrm{ZnS}$.

Although the emission spectra shape appeared similar, the decrease or increase in the PL intensity is evidence that the dopants enter into $\mathrm{ZnS}$ lattice. Only $\mathrm{Ga}(0.1)-\mathrm{ZnS}$ showed higher intensity compared to $\mathrm{ZnS}$.

The peak at $400 \mathrm{~nm}$ disappeared when $\mathrm{Cu}$ was doped in $\mathrm{ZnS}$. This confirms that the peak around this region was due to electron-hole recombination emission of $\mathrm{ZnS}$. No appreciable shifting of peak was noticed when $\mathrm{Cu}$ content increased. The peak intensity decreased with increasing $\mathrm{Cu}$ concentration. The decrease in intensity with increasing $\mathrm{Cu}$ content is due to repeated excitation within the copper dopant of the samples. Such a decrease in intensity with increasing copper loading was reported previously [34]. This was obvious for $\mathrm{Cu}(0.1)-\mathrm{ZnS}$ where it has the lowest PL intensity.

3.4. Elemental Analysis. The surface chemical composition and chemical states of a representative sample, $\mathrm{Ga}(0.1)$, $\mathrm{Cu}(0.01)-\mathrm{ZnS}$, were analyzed by XPS as shown in Figure 5. The main peaks with binding energies associated with $\mathrm{Zn}$ $\left(1025 \mathrm{eV}, \mathrm{Zn} 2 \mathrm{p}_{3 / 2}\right.$ and $\left.1048 \mathrm{eV}, \mathrm{Zn} 2 \mathrm{p}_{1 / 2}\right), \mathrm{Ga}(1149 \mathrm{eV}, \mathrm{Ga}$ 


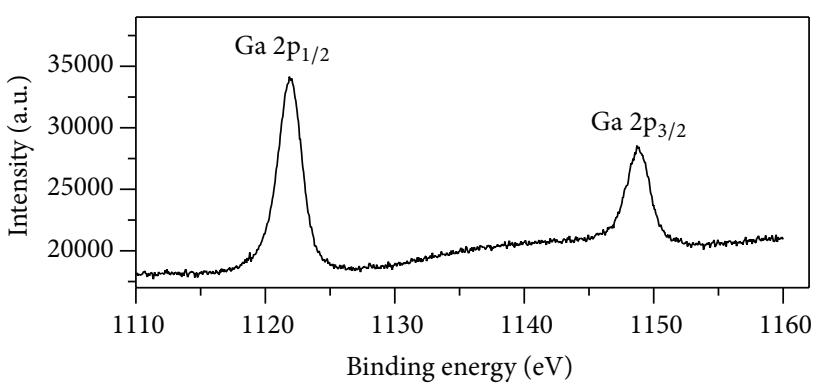

(a)

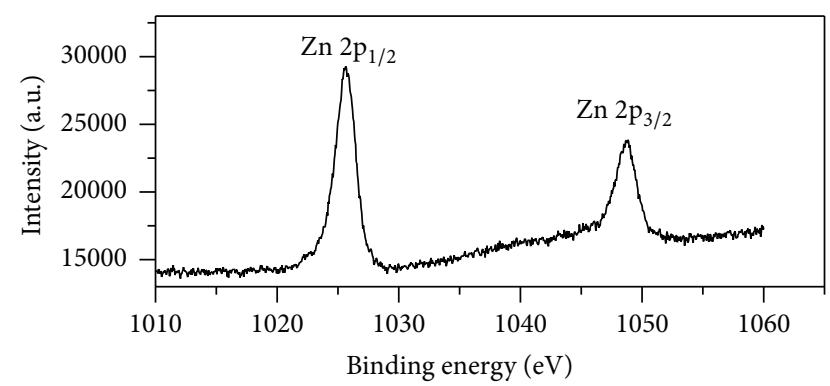

(b)

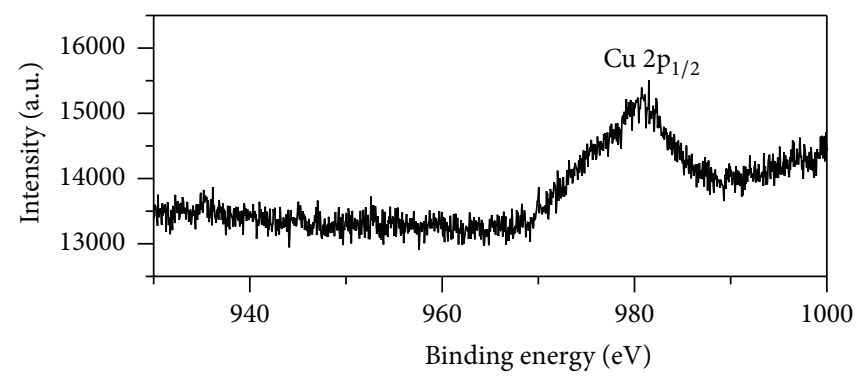

(c)

Figure 5: XPS spectra of Ga(0.1), $\mathrm{Cu}(0.01)-\mathrm{ZnS}$ : (a) Ga, (b) Zn, and (c) Cu.

$2 \mathrm{p}_{3 / 2}$ and $\left.1120 \mathrm{eV}, \mathrm{Ga} 2 \mathrm{p}_{1 / 2}\right), \mathrm{Cu}\left(981 \mathrm{eV}, 2 \mathrm{p}_{1 / 2}\right), \mathrm{S}(165 \mathrm{eV}$, $2 \mathrm{p}), \mathrm{C}(285 \mathrm{eV}, 1 \mathrm{~s})$, and $\mathrm{O}(530 \mathrm{eV}, 1 \mathrm{~s})$ were observed. The $\mathrm{C}$ and $\mathrm{O}$ peaks may originate from absorbed gaseous molecules and contamination caused by air exposure. The binding energies were also calibrated using carbon. There were no other element peaks indicating that the obtained product is relatively pure.

The binding energy corresponding to Ga $2 p_{1 / 2}$ and $2 p_{3 / 2}$ was found to shift towards higher values from the standard $1144 \mathrm{eV}$ and $1117 \mathrm{eV}$ to $1149 \mathrm{eV}$ and $1120 \mathrm{eV}$, respectively. The shift of binding energy suggests some chemical interaction between the $\mathrm{Ga}^{3+}$ ions with other elements in the sample. A small peak corresponding to $\mathrm{Ga} 3 \mathrm{~d}_{3 / 3}$ at $19 \mathrm{eV}$ was also observed. The signal with binding energy of $20.9 \mathrm{eV}$ is consistent with a trivalent $\mathrm{Ga}$ oxidation state [35]. The peaks of 1025.45 and $1048.85 \mathrm{eV}$ can be attributed to $\mathrm{Zn} 2 \mathrm{p}_{3 / 2}$ and $2 \mathrm{p}_{1 / 2}$, respectively. This reveals the oxidation state of $\mathrm{Zn}^{2+}$ in the sample $[36,37]$. The increase in the binding energy of $\mathrm{Zn}$ $2 \mathrm{p}$ bands may be seen as due to the interaction of $\mathrm{Zn}^{2+}$ ions with other elements on the surface. The measured binding energy of only $\mathrm{Cu} 2 \mathrm{p}_{1 / 2}$ was detected at 981.5 which was far from the value reported by other groups at around 950 [38]. This binding energy indicates that oxidation state of copper present was +2 . Apart from being detected in a very small amount, $\mathrm{Cu}$ probably interacts with other metal ions present or forms new bond; thus the peak was largely shifted to higher energy. The single S2p peak at $165.75 \mathrm{eV}$ was indicative of sulfur present as the divalent sulfur. The chemical compositions from XRF further support these findings.

The elemental contents of $\mathrm{Ga}, \mathrm{Cu}, \mathrm{Zn}$, and $\mathrm{S}$ of all samples except $\mathrm{ZnS}$ were analyzed by XRF as listed in Table 2 . The XRF data is similar to the added mol ratio during synthesis. The amount of $\mathrm{Cu}$ presence as detected by XRF increased
TABLE 2: Chemical composition of $\mathrm{ZnS}$ doped samples by XRF.

\begin{tabular}{lccccc}
\hline Entry & Samples & $\mathrm{Zn}$ & $\mathrm{Cu}$ & $\mathrm{Ga}$ & $\mathrm{S}$ \\
\hline 1 & $\mathrm{Cu}(0.1)-\mathrm{ZnS}$ & 52.57 & 6.96 & - & 32.33 \\
2 & $\mathrm{Ga}(0.1)-\mathrm{ZnS}$ & 49.7 & - & 4.46 & 28.2 \\
3 & $\mathrm{Ga}(0.1), \mathrm{Cu}(0.01)-\mathrm{ZnS}$ & 36.49 & 0.69 & 3.37 & 20.27 \\
4 & $\mathrm{Ga}(0.1), \mathrm{Cu}(0.03)-\mathrm{ZnS}$ & 48.82 & 2.05 & 4.47 & 25.09 \\
5 & $\mathrm{Ga}(0.1), \mathrm{Cu}(0.05)-\mathrm{ZnS}$ & 38.25 & 3.33 & 2.95 & 22.85 \\
\hline
\end{tabular}

TABLE 3: Comparison of chemical composition from XRF and XPS.

\begin{tabular}{lccccc}
\hline $\begin{array}{l}\text { Characterization } \\
\text { method }\end{array}$ & Sample & $\mathrm{Zn}$ & $\mathrm{Cu}$ & $\mathrm{Ga}$ & $\mathrm{S}$ \\
\hline $\mathrm{XRF}$ & $\mathrm{Ga}(0.1), \mathrm{Cu}(0.01)-\mathrm{ZnS}$ & 36.49 & 0.69 & 3.37 & 20.27 \\
$\mathrm{XPS}$ & $\mathrm{Ga}(0.1), \mathrm{Cu}(0.01)-\mathrm{ZnS}$ & 37.30 & 7.90 & 46.59 & 8.21 \\
\hline
\end{tabular}

with increasing amount of $\mathrm{Cu}$ during synthesis. From the elemental composition analysis, more $\mathrm{Ga}$ and $\mathrm{Cu}$ were detected on the surface (XPS) than in bulk (XRF) as compared to the representative sample $\mathrm{Ga}(0.1), \mathrm{Cu}(0.01)-\mathrm{ZnS}$ as shown in Table 3. This illustrates that both $\mathrm{Ga}$ and $\mathrm{Cu}$ are dispersed on the surface rather than present inside the bulk.

3.5. Photocatalytic Activity. Figure 6 shows hydrogen evolution from an aqueous solution containing sacrificial reagents $\mathrm{SO}_{3}{ }^{2-}$ and $\mathrm{S}_{2}{ }^{2-}$ over $\mathrm{Cu}(0.1)-\mathrm{ZnS}$ and $\mathrm{Ga}(0.1), \mathrm{Cu}(x)-\mathrm{ZnS}$ powder under visible light irradiation. Pure $\mathrm{ZnS}$ and $\mathrm{Ga}(0.1)$ $\mathrm{ZnS}$ were not active to produce hydrogen under visible light irradiation due to their large band gap energy. The rate of hydrogen evolution over $\mathrm{Cu}(0.1)-\mathrm{ZnS}$ was only $1.96 \mu \mathrm{mol} / \mathrm{h}$. As $\mathrm{Ga}$ and $\mathrm{Cu}$ were codoped, the photocatalytic activity was greatly enhanced. The highest activity was observed for 


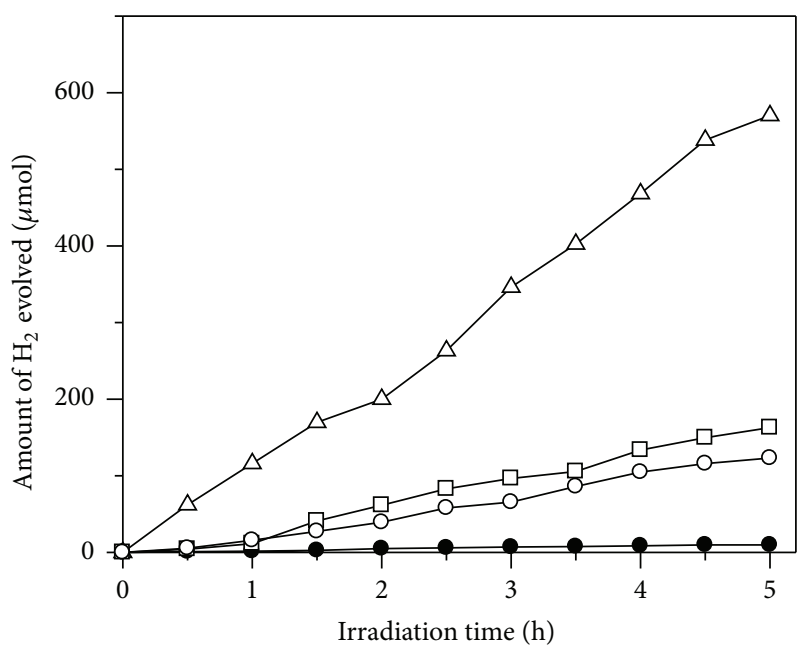

Figure 6: Photocatalytic hydrogen evolution on $\mathrm{Cu}(0.1)-\mathrm{ZnS}$ (๑), $\mathrm{Ga}(0.1), \mathrm{Cu}(0.01)-\mathrm{ZnS}(\triangle), \mathrm{Ga}(0.1), \mathrm{Cu}(0.03)-\mathrm{ZnS}$ (口), and $\mathrm{Ga}(0.1), \mathrm{Cu}(0.05)-\mathrm{ZnS}(\mathrm{O})$ under visible light irradiation.

$\mathrm{Ga}(0.1), \mathrm{Cu}(0.01)-\mathrm{ZnS}$ with the rate of hydrogen evolution reaching $114 \mu \mathrm{mol} / \mathrm{h}$. Although the visible light absorption increased with increasing $\mathrm{Cu}$ content, the photocatalytic activity decreased. The high photocatalytic activity observed for $\mathrm{Ga}(0.1), \mathrm{Cu}(0.01)-\mathrm{ZnS}$ was dependent not only on the amount of $\mathrm{Cu}$ dopant but also on other factors. The presence of $\mathrm{Ga}$ was constant for each of the codoped samples. Small amount of $\mathrm{Ga}$ occupies the defect sites of $\mathrm{ZnS}$ [39]. It can be deduced that when optimum amount of $\mathrm{Ga}$ and $\mathrm{Cu}$ was used, they produce a synergistic effect that facilitates efficient charge carriers to participate in the photocatalytic activity. On the other hand, doping of a large amount of $\mathrm{Cu}$ ions would lead to charge recombination. Therefore, finding the optimum amount of dopants is crucial.

Another possible reason is that $\mathrm{Ga}(0.1), \mathrm{Cu}(0.01)-\mathrm{ZnS}$ possessed the smallest crystallite size as can be seen from the broad XRD peaks and largest surface area. Small crystallite size would facilitate fast transportation of photogenerated electrons from the bulk to surface avoiding their recombination in the bulk of the photocatalyst. On the other hand, enhancement in the surface area could afford more reaction sites. Both small crystallite size and large surface area are beneficial for enhanced photocatalytic activity. For this system, there should be a balance between the enhancement of visible light absorption and the increased electron-hole recombination. Therefore, decreased electron-hole recombination is desired for photocatalytic hydrogen process.

The stability of $\mathrm{Ga}(0.1), \mathrm{Cu}(0.01)-\mathrm{ZnS}$ was also examined for 15 hours as shown in Figure 7 without changing the sacrificial agent. For every 5 hours, the reaction system is degassed using nitrogen. The photocatalytic activity merely decreases at 5\% after 15 hours. There was no sign of activity deterioration under the current photocatalytic reaction test in the presence of sacrificial reagents. It is important to note that there were no distinct changes in the physical properties after 15 hours of photoactivity measurements, indicating good stability of photocatalysts in the photocatalytic reaction.

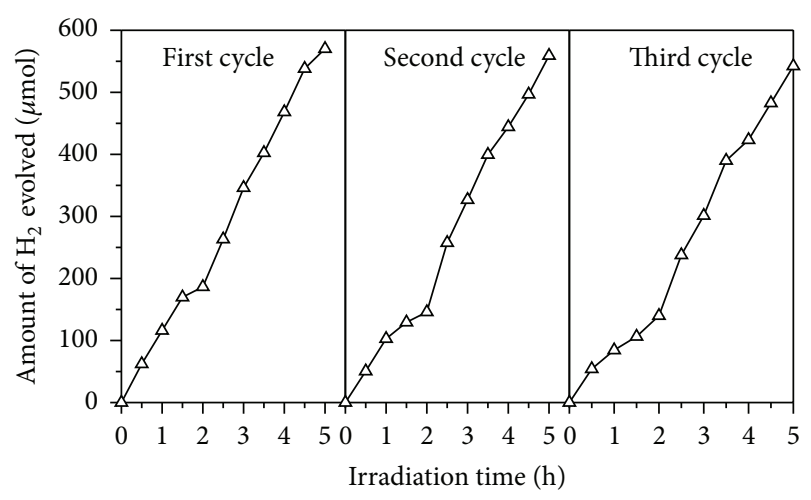

Figure 7: Stability test of $\mathrm{Ga}(0.1), \mathrm{Cu}(0.01)-\mathrm{ZnS}$ for 3 cycles under visible light irradiation.

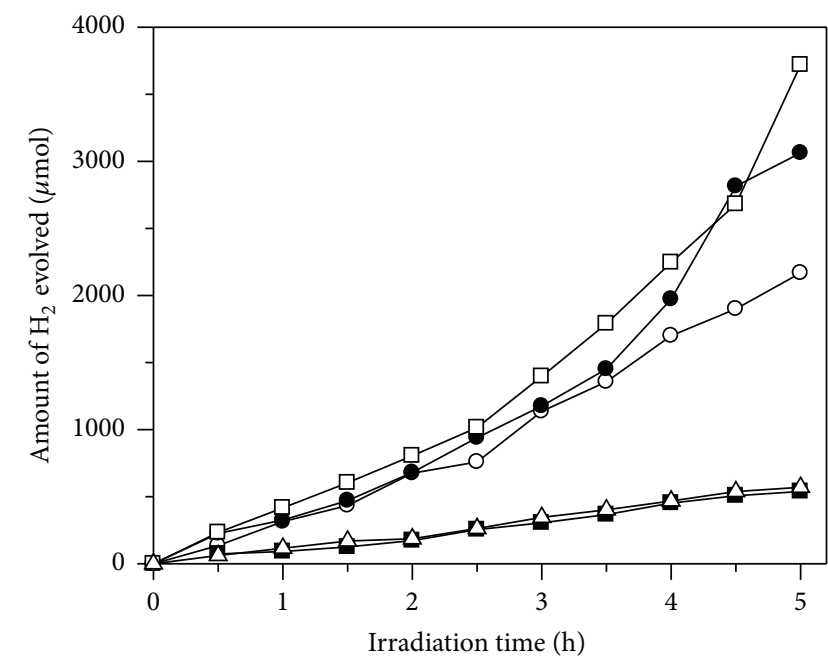

Figure 8: Photocatalytic hydrogen evolution on $\mathrm{Ga}(0.1), \mathrm{Cu}(0.01)$ $\mathrm{ZnS}(\triangle), \quad \mathrm{Ru}(0.1 \mathrm{wt} \%)-\mathrm{Ga}(0.1), \mathrm{Cu}(0.01)-\mathrm{ZnS}(O), \quad \mathrm{Ru}(0.3 \mathrm{wt} \%)-$ $\mathrm{Ga}(0.1), \mathrm{Cu}(0.01)-\mathrm{ZnS}(\bullet), \mathrm{Ru}(0.5 \mathrm{wt} \%)-\mathrm{Ga}(0.1), \mathrm{Cu}(0.01)-\mathrm{ZnS}$ (口), and $\mathrm{Ru}(1 \mathrm{wt} \%)-\mathrm{Ga}(0.1), \mathrm{Cu}(0.01)-\mathrm{ZnS}(\mathbf{\square})$.

3.6. Cocatalyst. To improve further the photocatalytic activity, the effect of loading $\mathrm{Ru}$ as cocatalyst onto $\mathrm{Ga}(0.1)$, $\mathrm{Cu}(0.01)-\mathrm{ZnS}$ was examined. Figure 8 shows the dependence of hydrogen evolution amount from an aqueous $\mathrm{Na}_{2} \mathrm{~S}$ and $\mathrm{Na}_{2} \mathrm{SO}_{3}$ solution over $\mathrm{Ga}(0.1), \mathrm{Cu}(0.01)-\mathrm{ZnS}$ on the loading amount of $\mathrm{Ru}$ cocatalyst. Before reaction, $\mathrm{Ru}(0.1,0.3,0.5$, and $1 \mathrm{wt} \%$ ) was deposited as a cocatalyst on photocatalysts by photodeposition method under visible light. Photocatalytic activity was markedly improved when the $\mathrm{Ru}$ cocatalyst was loaded on the $\mathrm{Ga}(0.1), \mathrm{Cu}(0.01)-\mathrm{ZnS}$ sample. It is well known that $\mathrm{Ru}$ has metallic characteristics with a higher conduction band potential above $2 \mathrm{H}^{+} / \mathrm{H}_{2}$; hence reaction facilitates photoinduced electron/hole separation and thus inhibits their recombination effectively [40]. As shown in Figure 8, the hydrogen production rate increased with the increase of $\mathrm{Ru}$ content. When the $\mathrm{Ru}$ content increased to $0.5 \mathrm{wt} \%$, the maximum activity for hydrogen production was attained. The average rate of hydrogen evolution amounts to $744 \mu \mathrm{mol} / \mathrm{h}$, corresponding to an apparent quantum yield at 
$425 \mathrm{~nm}$ of $0.14 \%$. Both below and above $0.5 \mathrm{wt} \% \mathrm{Ru}$ content, the hydrogen evolution rate was lower. $\mathrm{Ru}$ as cocatalyst at optimum amount promoted the photogenerated charges separation and reduced recombination rate while acting as active sites for hydrogen production.

\section{Conclusions}

In summary, we have successfully synthesized $\mathrm{Ga}(0.1), \mathrm{Cu}(x)$ $\mathrm{ZnS}(x=0.01,0.03,0.05)$ by hydrothermal method. These photocatalysts are active for photocatalytic hydrogen production under visible light irradiation. Ga was proposed as an effective dopant to introduce oxygen vacancies acting as efficient electron trap. The addition of $\mathrm{Cu}$ at optimum amount for $\mathrm{Ga}(0.1), \mathrm{Cu}(0.01)-\mathrm{ZnS}$ not only makes this photocatalyst active under visible light but also promotes the photocatalytic activity with hydrogen production rate of $114 \mu \mathrm{mol} / \mathrm{h}$. Ru cocatalyst further improved the photocatalytic activity of $\mathrm{Ga}(0.1), \mathrm{Cu}(0.01)-\mathrm{ZnS}$ by 6.5 times. This works shows that $\mathrm{Ga}$ is an effective dopant for photocatalytic hydrogen production although Ga did not contribute to the visible light response of the photocatalyst. Codoping of two metal ions provided synergistic effect for the development of new photocatalyst for hydrogen production.

\section{Conflict of Interests}

The authors declare that there is no conflict of interests regarding the publication of this paper.

\section{Acknowledgment}

Financial support from the Ministry of Science, Technology and Innovation through the National Science Fellowship is greatly acknowledged (Melody Kimi).

\section{References}

[1] R. M. Navarro, M. C. Sánchez-Sánchez, M. C. Alvarez-Galvan, F. del Valle, and J. L. G. Fierro, "Hydrogen production from renewable sources: biomass and photocatalytic opportunities," Energy \& Environmental Science, vol. 2, no. 1, pp. 35-54, 2009.

[2] R. M. Navarro Yerga, M. Consuelo Álvarez Galván, F. del Valle, J. A. Villoria de la Mano, and J. L. G. Fierro, "Water splitting on semiconductor catalysts under visiblelight irradiation," ChemSusChem, vol. 2, no. 6, pp. 471-485, 2009.

[3] P. V. Kamat, "Meeting the clean energy demand: nanostructure architectures for solar energy conversion," Journal of Physical Chemistry C, vol. 111, no. 7, pp. 2834-2860, 2007.

[4] J. Zhu and M. Zäch, "Nanostructured materials for photocatalytic hydrogen production," Current Opinion in Colloid \& Interface Science, vol. 14, no. 4, pp. 260-269, 2009.

[5] K. Maeda and K. Domen, "New non-oxide photocatalysts designed for overall water splitting under visible light," Journal of Physical Chemistry C, vol. 111, no. 22, pp. 7851-7861, 2007.

[6] A. Kudo and Y. Miseki, "Heterogeneous photocatalyst materials for water splitting," Chemical Society Reviews, vol. 38, no. 1, pp. 253-278, 2009.

[7] J.-F. Reber and K. Meier, "Photochemical production of hydrogen with zinc sulfide suspensions," Journal of Physical Chemistry, vol. 88, no. 24, pp. 5903-5913, 1984.
[8] D. Hayes, F. Grieser, and D. N. Furlong, "Kinetics of hydrogen production from illuminated $\mathrm{CdS} / \mathrm{Pt} / \mathrm{Na}_{2} \mathrm{SO}_{3}$ and $\mathrm{ZnS} / \mathrm{Pt} / \mathrm{Na}_{2} \mathrm{~S}$ dispersions," Journal of the Chemical Society, Faraday Transactions, vol. 86, no. 21, pp. 3637-3640, 1990.

[9] S. K. Apte, S. N. Garaje, S. S. Arbuj et al., "A novel template free, one pot large scale synthesis of cubic zinc sulfide nanotriangles and its functionality as an efficient photocatalyst for hydrogen production and dye degradation," Journal of Materials Chemistry, vol. 21, no. 48, pp. 19241-19248, 2011.

[10] A. Kudo and M. Sekizawa, "Photocatalytic $\mathrm{H}_{2}$ evolution under visible light irradiation on $\mathrm{Zn}_{1-x} \mathrm{Cu}_{x} \mathrm{~S}$ solid solution," Catalysis Letters, vol. 58, no. 4, pp. 241-243, 1999.

[11] T. Arai, S.-I. Senda, Y. Sato et al., "Cu-doped ZnS hollow particle with high activity for hydrogen generation from alkaline sulfide solution under visible light," Chemistry of Materials, vol. 20, no. 5, pp. 1997-2000, 2008.

[12] A. Kudo and M. Sekizawa, "Photocatalytic $\mathrm{H}_{2}$ evolution under visible light irradiation on $\mathrm{Ni}$-doped $\mathrm{ZnS}$ photocatalyst," Chemical Communications, no. 15, pp. 1371-1372, 2000.

[13] J. Zhang, S. Liu, J. Yu, and M. Jaroniec, "A simple cation exchange approach to Bi-doped $\mathrm{ZnS}$ hollow spheres with enhanced UV and visible-light photocatalytic $\mathrm{H}_{2}$-production activity," Journal of Materials Chemistry, vol. 21, no. 38, pp. 14655-14662, 2011.

[14] R. Sasikala, V. Sudarsan, C. Sudakar, R. Naik, T. Sakuntala, and S. R. Bharadwaj, "Enhanced photocatalytic hydrogen evolution over nanometer sized Sn and Eu doped titanium oxide," International Journal of Hydrogen Energy, vol. 33, no. 19, pp. 4966-4973, 2008.

[15] R. Jaiswal, N. Patel, D. C. Kothari, and A. Miotello, "Improved visible light photocatalytic activity of $\mathrm{TiO}_{2}$ co-doped with Vanadium and Nitrogen," Applied Catalysis B: Environmental, vol. 126, pp. 47-54, 2012.

[16] M.-Y. Lu, M.-P. Lu, Y.-A. Chung, M.-J. Chen, Z. L. Wang, and L.J. Chen, "Intercrossed sheet-like Ga-doped ZnS nanostructures with superb photocatalytic actvitiy and photoresponse," The Journal of Physical Chemistry C, vol. 113, no. 29, pp. 12878-12882, 2009.

[17] N. Arai, N. Saito, H. Nishiyama, Y. Inoue, K. Domen, and K. Sato, "Overall water splitting by $\mathrm{RuO}$ 2-dispersed divalent-iondoped GaN photocatalysts with d 10 electronic configuration," Chemistry Letters, vol. 35, no. 7, pp. 796-797, 2006.

[18] N. Arai, N. Saito, H. Nishiyama et al., "Effects of divalent metal ion $\left(\mathrm{Mg}^{2+}, \mathrm{Zn}^{2+}\right.$ and $\left.\mathrm{Be}^{2+}\right)$ doping on photocatalytic activity of ruthenium oxide-loaded gallium nitride for water splitting," Catalysis Today, vol. 129, no. 3-4, pp. 407-413, 2007.

[19] Y. C. Chen, C. H. Wang, W. T. Chen, B. H. Li, L. W. Tub, and C. P. Liu, "Undoped and Ga-doped hexagonal platelet interconnected ZnS nanowires: cathodoluminescence and metalsemiconductor electron transport transition," Scripta Materialia, vol. 64, no. 8, pp. 761-764, 2011.

[20] X. Zhang, D. Jing, M. Liu, and L. Guo, "Efficient photocatalytic $\mathrm{H}_{2}$ production under visible light irradiation over Ni doped $\mathrm{Cd}_{1-x} \mathrm{Zn}_{x} \mathrm{~S}$ microsphere photocatalysts," Catalysis Communications, vol. 9, no. 8, pp. 1720-1724, 2008.

[21] M. Kimi, L. Yuliati, and M. Shamsuddin, "Photocatalytic hydrogen production under visible light over $\mathrm{Cd}_{0.1} \mathrm{Sn}_{x} \mathrm{Zn}_{0.9-2 x} \mathrm{~S}$ solid solution photocatalysts," International Journal of Hydrogen Energy, vol. 36, no. 16, pp. 9453-9461, 2011.

[22] S. Zu, Z. Wang, B. Liu, X. Fan, and G. Qian, "Synthesis of nano- $\mathrm{Cd}_{x} \mathrm{Zn}_{1-x} \mathrm{~S}$ by precipitate-hydrothermal method and its 
photocatalytic activities," Journal of Alloys and Compounds, vol. 476, no. 1-2, pp. 689-692, 2009.

[23] S. Sain and S. K. Pradhan, "Mechanochemical solid state synthesis of $\left(\mathrm{Cd}_{0.8} \mathrm{Zn}_{0.2}\right) \mathrm{S}$ quantum dots: Microstructure and optical characterizations," Journal of Alloys and Compounds, vol. 509, no. 10, pp. 4176-4184, 2011.

[24] Y. Zhao, Y. Zhang, H. Zhu, G. C. Hadjipanayis, and J. Q. Xiao, "Low-temperature synthesis of hexagonal (wurtzite) $\mathrm{ZnS}$ nanocrystals," Journal of the American Chemical Society, vol. 126, no. 22, pp. 6874-6875, 2004.

[25] M. Saranya, R. Ramachandran, E. J. J. Samuel, S. K. Jeong, and A. N. Grace, "Enhanced visible light photocatalytic reduction of organic pollutant and electrochemical properties of $\mathrm{CuS}$ catalyst," Powder Technology, vol. 279, pp. 209-220, 2015.

[26] M. Saranya, C. Santhosh, R. Ramachandran et al., "Hydrothermal growth of $\mathrm{CuS}$ nanostructures and its photocatalytic properties," Powder Technology, vol. 252, pp. 25-32, 2014.

[27] U. T. D. Thuy, N. Q. Liem, C. M. A. Parlett, G. M. Lalev, and K. Wilson, "Synthesis of CuS and CuS/ZnS core/shell nanocrystals for photocatalytic degradation of dyes under visible light," Catalysis Communications, vol. 44, pp. 62-67, 2014.

[28] G. Zhang, X. Zou, J. Gong et al., "Characterization and photocatalytic activity of $\mathrm{Cu}$-doped $\mathrm{K}_{2} \mathrm{Nb}_{4} \mathrm{O}_{11}$," Journal of Molecular Catalysis A: Chemical, vol. 255, no. 1-2, pp. 109-116, 2006.

[29] B. Liu, L. Hu, C. Tang et al., "Self-assembled highly symmetrical $\mathrm{ZnS}$ nanostructures and their cathodoluminescence," Journal of Luminescence, vol. 131, no. 5, pp. 1095-1099, 2011.

[30] O. Kozák, P. Praus, K. Kočí, and M. Klementová, "Preparation and characterization of $\mathrm{ZnS}$ nanoparticles deposited on montmorillonite," Journal of Colloid and Interface Science, vol. 352, no. 2, pp. 244-251, 2010.

[31] G. R. Chaudhary, P. Bansal, and S. K. Mehta, "Recyclable CuS quantum dots as heterogeneous catalyst for Biginelli reaction under solvent free conditions," Chemical Engineering Journal, vol. 243, pp. 217-224, 2014.

[32] X. Qiu, M. Miyauchi, H. Yu, H. Irie, and K. Hashimoto, "Visible-light-driven $\mathrm{Cu}(\mathrm{II})-\left(\mathrm{Sr}_{1-y} \mathrm{Na}_{y}\right)\left(\mathrm{Ti}_{1-x} \mathrm{Mo}_{x}\right) \mathrm{O}_{3}$ photocatalysts based on conduction band control and surface ion modification," Journal of the American Chemical Society, vol. 132, no. 43, pp. 15259-15267, 2010.

[33] A. Datta, S. K. Panda, and S. Chaudhuri, "Phase transformation and optical properties of Cu-doped ZnS nanorods," Journal of Solid State Chemistry, vol. 181, no. 9, pp. 2332-2337, 2008.

[34] M. Wang, L. Sun, X. Fu, C. Liao, and C. Yan, "Synthesis and optical properties of $\mathrm{ZnS}: \mathrm{Cu}(\mathrm{II})$ nanoparticles," Solid State Communications, vol. 115, no. 9, pp. 493-496, 2000.

[35] A. S. Deshpande, D. G. Shckukin, E. Ustinovicetti, M. Antoni, and R. A. Carusoh, "Titania and mixed titania/aluminum, gallium, or indium oxide spheres: sol-gel/template synthesis and photocatalytic properties," Advanced Functional Materials, vol. 15, no. 2, pp. 239-245, 2005.

[36] Y.-N. NuLi, Y.-Q. Chu, and Q.-Z. Qin, "Nanocrystalline $\mathrm{ZnFe}_{2} \mathrm{O}_{4}$ and $\mathrm{Ag}$-doped $\mathrm{ZnFe}_{2} \mathrm{O}_{4}$ films used as new anode materials for Li-ion batteries," Journal of the Electrochemical Society, vol. 151, no. 7, pp. A1077-A1083, 2004.

[37] Y. Sharma, N. Sharma, G. V. S. Rao, and B. V. R. Chowdari, "Listorage and cyclability of urea combustion derived $\mathrm{ZnFe}_{2} \mathrm{O}_{4}$ as anode for Li-ion batteries," Electrochimica Acta, vol. 53, no. 5, pp. 2380-2385, 2008.

[38] I. H. Tseng, J. C. S. Wu, and H. Y. Chou, "Effects of solgel procedures on the photocatalysis of $\mathrm{Cu} / \mathrm{TiO}_{2}$ in $\mathrm{CO}_{2}$ photoreduction," Journal of Catalysis, vol. 221, no. 2, pp. 432$440,2004$.

[39] A. Ali, X. Zhao, A. Ali et al., "Enhanced photocatalytic activity of $\mathrm{ZnO}$ nanorods grown on Ga doped seed layer," Superlattices and Microstructures, vol. 83, pp. 422-430, 2015.

[40] J.-Y. Liu, B. Garg, and Y.-C. Ling, " $\mathrm{Cu}_{x} \mathrm{Ag}_{y} \mathrm{In}_{z} \mathrm{Zn}_{k} \mathrm{~S}_{m}$ solid solutions customized with $\mathrm{RuO}_{2}$ or $\mathrm{Rh}_{1.32} \mathrm{Cr}_{0.66} \mathrm{O}_{3}$ co-catalyst display visible light-driven catalytic activity for $\mathrm{CO}_{2}$ reduction to $\mathrm{CH}_{3} \mathrm{OH}$,' Green Chemistry, vol. 13, no. 8, pp. 2029-2031, 2011. 

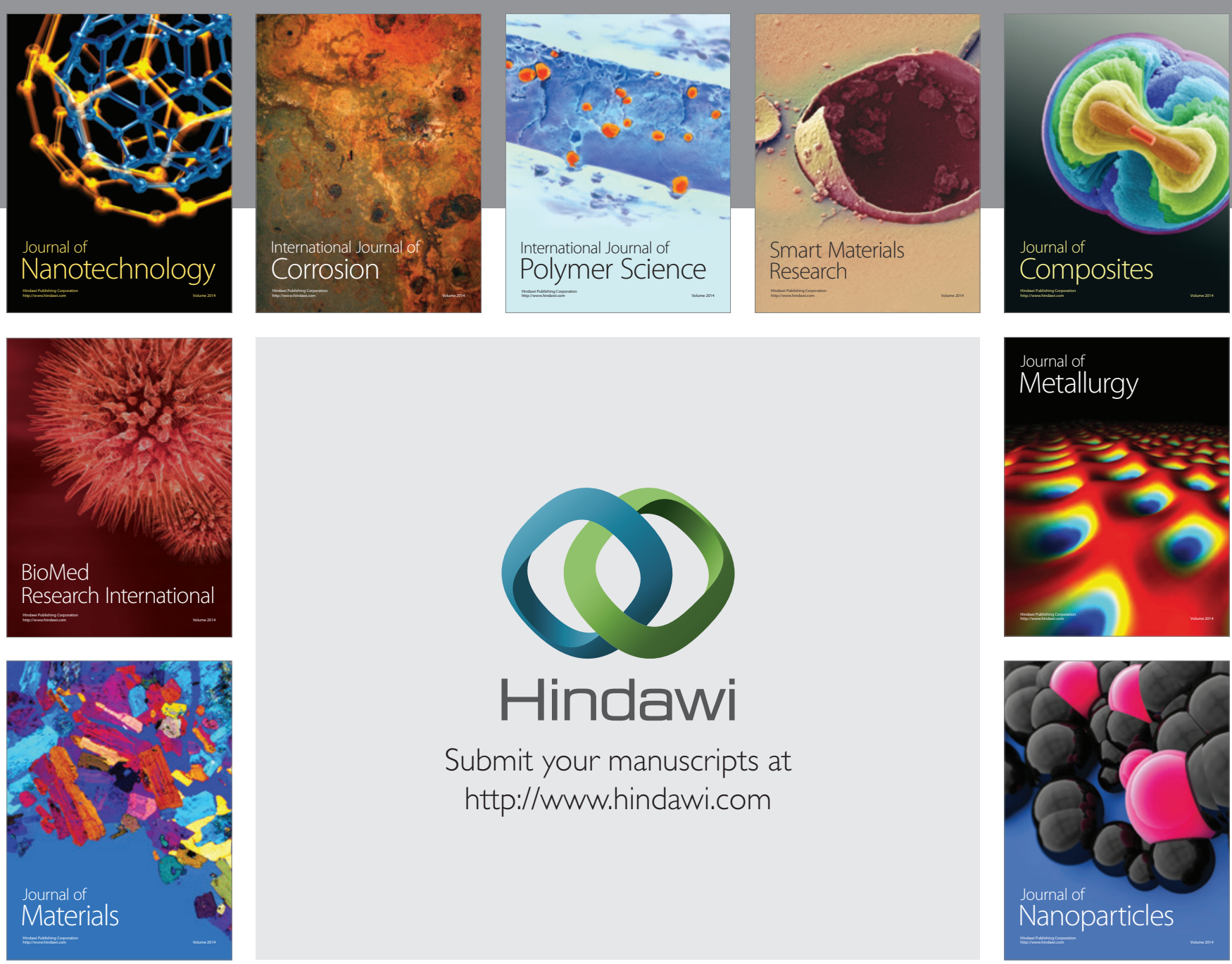

Submit your manuscripts at http://www.hindawi.com
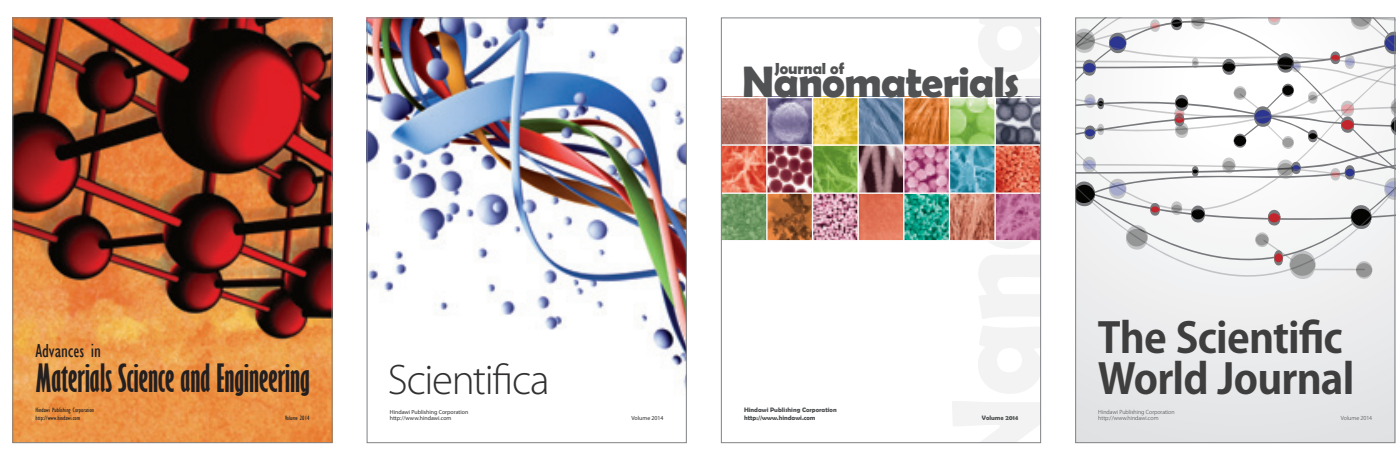

\section{The Scientific World Journal}
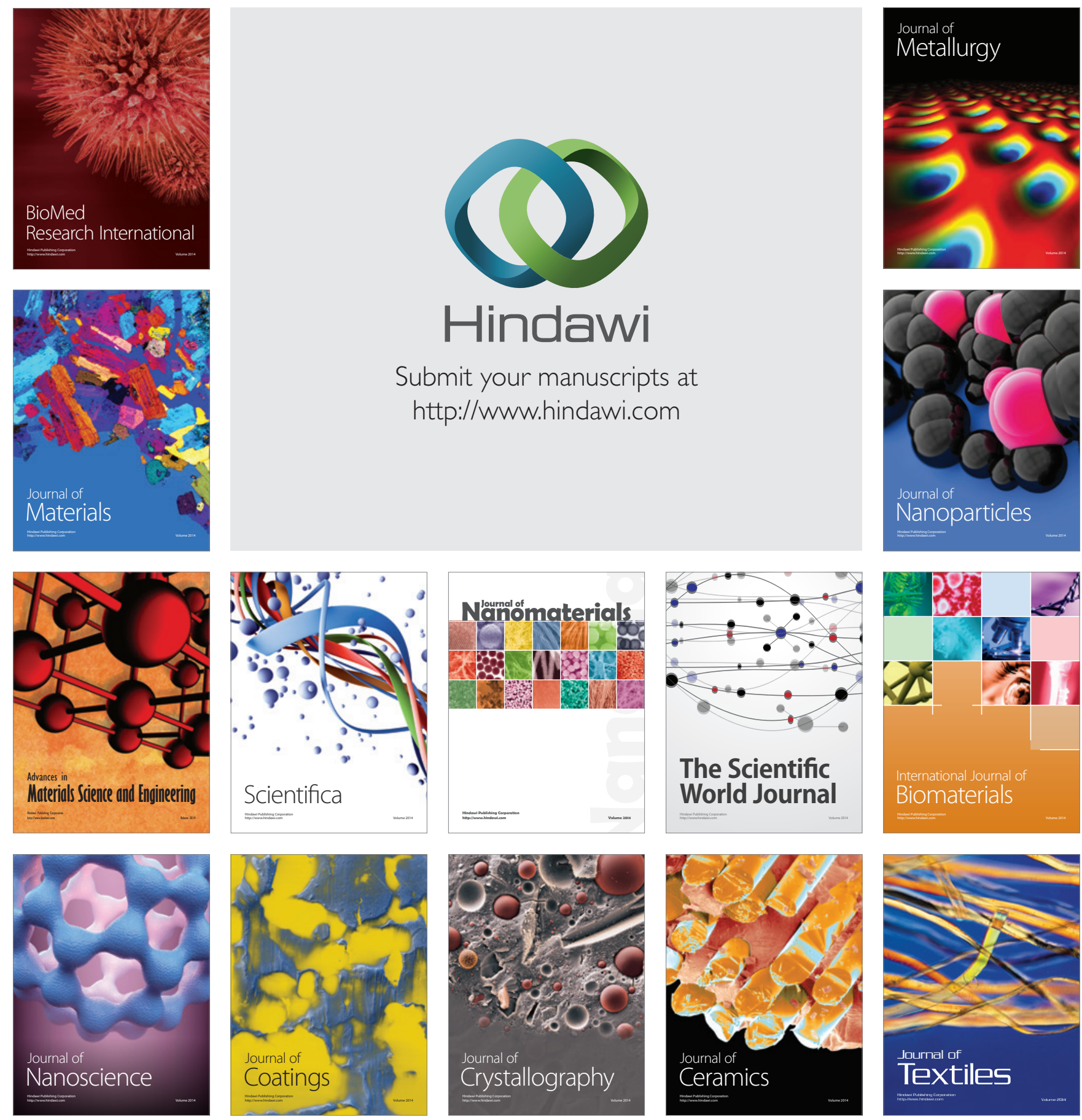